Irish chemist and administrator, Sir Robert Kane, to arouse interest in the application of science to industry. In 1867 the Museum became the Royal College of Science for Ireland. This College was transferred to University College, Dublin, in 1926 and the chair of chemistry merged in that set up by Cardinal Newman in the Irish Catholic University in 1856.

The occupants of the chair established in 1796 were William Higgins, F.R.S. (1796-1825) ; Edmund Davy, F.R.S. (1826-54); chair transferred to the Museum of Irish Industry: W. K. Sullivan (185467) ; chair transferred to the Royal College of Science for Ireland: W. K. Sullivan (1867-73); Robert Galloway (1873-79); Sir Walter Hartley, F.R.S. (1879-1911); Sir Gilbert Morgan, F.R.S. (1912-16) ; W. E. Adeney (1916-23). The chair was then left vacant pending transfer to University College, Dublin. It will be seen that this chair is nearly as old as the oldest in Scotland (Aberdeen, 1793), but is long antedated by that at Cambridge (1702).

Nature, 169, 160 (1952).

${ }^{2}$ Nature, 169, 292 (1952).

\section{TERCENTENARY OF THE LEOPOLDINA ACADEMY, HALLE}

T HE Leopoldina Academy (Deutsche Akademie der Naturforscher) at Halle (Saale), in the East Zone of Germany, celebrated its tercentenary during February 16-17. The University of Halle co-operated closely with the Academy throughout the proceedings. Addresses of congratulation were received from the Royal Society, the Cambridge Philosophical Society and the Royal Society of Edinburgh.

After addresses of welcome by the first vicepresident, Prof. Otto Schlüter, and others, a historical account of the Academy was given by Prof. Rudolph Zaunick, of Dresden. The programme of future work laid down in this connexion is primarily to resume and speed up publication projects in abeyance since the War. The Academy's journal, the Nova Acta Leopoldina, has completed Vol. 14 (New Series) with the appearance of Heft 5, and will continue. The Commentary on Euclid Book I by Proclus Diadochus (A.D. 410-485) has appeared. A complete edition is in progress, in fourteen volumes of text with commentary, of all Goethe's scientific works, of which the Academy has already brought out a very large index. These and other beautifully produced publications were on view in the Library of the Leopoldina Academy. Losses of valuable records and collections were, however, also noted.

At the scientific session on the second day, Prof. Hans Georg Kienle, of Heidelberg, discussed cosmical theory of the past fifty years. Prof. Max Bürger, of Leipzig, was too ill to give his lecture, "Die Lebensschicksale des menschlichen Herzens", and his place was taken by Dr. Max Ratschow, of Halle-Wittenberg, who spoke on problems of old age ("Úber die Verhütung von Alters. und Aufbrauchsschäden unter besonderer Rücksichtigung der hormonalen Therapie"). Ageing, which generally speaking is a drying-up process, connected with a reduced waterabsorption and water-retention capacity of tissues, is largely caused through disturbance of hormonal balance, and a natural approach is to redress this balance as far as possible. Prof. Hans Theo Schreus, of Düsseldorf, under the title "Besondere Gesichtspunkte bei der Behandlung mit Chemotherapeutices und Antibiotices von Geschlechtskrankheiten", gave an account of his researches into the treatment of venereal diseases, with special reference to the increase in bacterial resistance against penicillin during the years 1949-5l. He has studied in detail the effect of combining the chemotherapeutics terramycin, streptomycin, penicillin with one another and with other antibiotics, and has tabulated the correlation coefficients obtained. He also described the results in serum reactions of saturation treatment or short-term treatment with penicillin-bismuthsalvarsan.

Finally, Prof. Kurt Mothes, of Halle-Gatersleben, gave an address entitled "Die stoffliche Organisation der Pflanze". His theme was the lack of parallelism between complexity of organization and multiplicity of chemical substances in living organisms. Metabolic products found in the more complex organisms, such as animal bodies, in particular the human body, are neither very numerous nor very complex; thousands of other substances are present in lower forms of life, such as plants and micro-organisms. One reason for the variety of products found in lower organisms may be their lack of secretory mechanism, which favours storage, whereas, for the animal body, rapid excretion is typical. Referring to the virus world, Prof. Mothes suggested that not only do viruses vary considerably in size, but also many may exist besides those that manifest themselves by pathological effects.

The occasion was used further to honour the memory of Prof. Emil Abderhalden, whose place as president has not yet been filled.

Social gatherings forming part of the celebrations included a reception by members of the East Zone Government in Berlin, one by the local Government of Sachsen-Anhalt, and musical and dramatic performances.

\section{INDIAN SCIENCE CONGRESS}

\section{THIRTY-NINTH SESSION}

$T$ HE Indian Science Congress has been holding its annual sessions since the year 1914 at different towns and cities of India with the view of enabling eminent men of science of India as well as from abroad to meet on a common platform of intellectual kinship and to keep abreast of the times in discussions of scientific problems. The 1952 session was held early in January in Calcutta, which has always been one of the nerve-centres of India's intellectual life. The meeting-place was the historic compound of the Presidency College, Calcutta, which also saw the birth of the Indian Science Congress thirty-nine years ago.

In a spectacular pandal bedecked with floral and artistic designs and packed to its capacity of more than six thousand people, the session was opened by the chanting of Vedic hymns and the recitation of Vande Mataram. H.E. Dr. H. C. Mukerji, Governor of West Bengal, welcomed the distinguished gathering of scientific workers who had come to attend the session; and he urged that, although imported from the West, the modern scientific spirit should not be looked at askance by the people of India. In the course 
of another address, Mr. Justice S. N. Banerji, vicechancellor of the University of Calcutta and chairman of the Reception Committee for the meeting, exhorted scientific men to bring their researches to bear upon national progress and international peace, and suggested that much could be done by the collective effort of world scientists to prevent the manufacture of destructive weapons. The Honourable Dr. B. C. Roy, Chief Minister of West Bengal, inaugurating the session, laid stress on the humanitarian aspect of scientific thought and said that both the man of science and the administrator should think in terms of the human mind for the progress of the world.

Then the Honourable Shri Jawaharlal Nehru, Prime Minister of India, delivered an address, in the course of which he called upon scientific workers of every rank and level to lend him their active cooperation in the solution of the gigantic problems that are facing the teeming millions of India. Mentioning that the setting up of national laboratories was a matter of pride for the people of India, he observed that the masses ought to realize the importance of the role that scientific men have to take in the building up of a truly modern India.

Dr. J. N. Mukherji, director of the Central Building Research Institute, Roorkee, the president-elect of the session, in his presidential address entitled "Science and our Problems: Science and the Yield per Acre", urged scientific workers to ask themselves how far they are wielding their influence in the planning and implementation of the reconstruction programmes of the newly born Indian Republic. He added that planning is no less imperative for successful scientific research and training than for any other undertaking. Dr. Mukherji disapproved of the pursuit of science with a purely academic object in virtual isolation from the wider spheres of industry and agriculture. The improvement of social and economic conditions, he pointed out, would depend to a large extent upon the dissemination of accurate scientific knowledge. He recommended the formation of scientific societies for the maintenance of a proper standard of research, in the absence of which the wheels of national progress would be clogged.

The session was attended by about forty distinguished men of science from Great Britain, the United States, Switzerland, Denmark, West Germany, the U.S.S.R., Australia and Japan, among whom were Prof. J. B. S. Haldane (Weldon professor of biometry, University College, London), Prof. M. Heidelberger (professor of biochemistry in Columbia University, New York), Prof. C. B. Fawcett (emeritus professor of geography in the University of London), and Dr. E. C. Bullard (director of the National Physical Laboratory, Teddington). The presence of these visitors was a source of considerable enthusiasm and inspiration for their Indian colleagues.

The Congress met in thirteen sections : mathematics, statistics, botany, anthropology and archæology, chemistry, geology and geography, medical and veterinary sciences, physics, engineering and metallurgy, physiology, psychology and educational sciences, agricultural sciences, and zoology and entomology.

Among the presidential addresses of great interest and popularity were, "Some Aspects of Crystal Magnetism" (Physics Section), "Etiology of Cancer" (Medical and Veterinary Sciences Section), "Some Recent Methods of Solving Problems of Equilibrium and Vibration" (Mathematics Section), and "Technical Education" (Engineering and Metallurgy Section).
The presidential address at the anniversary meeting of the National Institute of Sciences of India was delivered by Dr. S. L. Hora on "Adaptation and Evolution".

During the sectional meetings some seven hundred research papers communicated by scholars all over the country were read and discussed. A volume of abstracts of these papers was published and distributed by the Association to help the smooth progress of discussions.

Among the significant symposia held during the session mention may be made of the following: "Soil Research in India", organized by the National Institute of Sciences of India and opened by Dr. J. N. Mukherji, "Fermentation Technology" (Chemistry Section), "Is Evolution Purposive?" (Botany and Zoology Sections), "Tamily Types and Changes in the Family of India" (Anthropology and Psychology Sections), "Geography of Crop Plants" (Botany Section), "Refugee Problem in Bengal" (Anthropology Section), "River Control" (Engineering and Metallurgy Section), and "Mathematical Teaching and Research in India", opened by Dr. B. N. Prasad. In view of the great importance of this subject, it has been agreed that the symposium will be continued from year to year for arriving at definite conclusions about the ways and means of reforming mathematical teaching and research in India.

A number of popular lectures on various topics were delivered by some of the foreign visitors and others. Some of them were: "Relation of Biology with other Sciences", by Prof. J. B. S. Haldane; "The Ocean Floor", by Dr. E. C. Bullard; "Antibiotics", by Dr. J. H. Kane; "Story of Monazite Sands", by Sir Shanti Bhatnagar; "Fisheries of South-East Asia", by Dr. G. L. Kesteven ; and "Defence Sciences and their Organization", by Dr. D. S. Kothari.

One of the mot instructive and informative features of the session was the Science Exhibition, at which exhibits from various scientific firms were displayed. During the evenings entertainment in the form of dance-dramas, Indian dances and music was offered by local artists and amateurs of the colleges and the University of Calcutta. Another interesting feature of the session was the arrangement for scientific excursions to local places of interest and beauty spots and also visits to the Tata Iron and Steel Works and the National Metallurgical Laboratory of Jamshedpur, Chittaranjan Locomotive Works, Damodar Valley Corporation, Mayurakshi Reservoir Project and the Indian Institute of Technology, Kharagpur.

To synchronize with the annual session of the Indian Science Congress a large number of scientific associations and societies like the National Institute of Sciences of India, the Indian Physicel Society, the Indian Chemical Society, and many others held their annual meetings. The Geological, Mining and Metallurgical Society of India also celebrated its silver jubilee this year.

At the general meeting of the Science Congress, Dr. D. M. Bose, director of the Bose Research Institute of Calcutta, was elected president of its fortieth session, which will be held at Lucknow in January 1953. Dr. B. N. Prasad, University of Allahabad, and Dr. S. R. Sen Gupta, Bengal Engineering College, Shibpur, were elected general secretaries, and Prof. P. C. Mahalanobis was elected treasurer.
B. N. Prasad 